\title{
The Role of Arbuscular Mycorrhizal Fungi Density and Diversity on the Growth and Biomass of Corn and Sorghum Forage in Trapping Culture
}

\author{
M. Husein ${ }^{a}$, N. Umami ${ }^{a, *}$, A. Pertiwiningrum ${ }^{a}$, M. M. Rahman ${ }^{b}$, \& D. Ananta ${ }^{a}$ \\ aDepartment of Animal Science, Faculty of Animal Science, Universitas Gadjah Mada \\ Jalan Fauna No 3, Bulaksumur, 55281, Yogyakarta, Indonesia \\ ${ }^{b}$ Faculty of Agro Based Industry, Institute of Food security and Sustainable Agriculture, Universiti Malaysia Kelantan \\ 17600 Jeli, Kelantan, Malaysia \\ *Corresponding author: nafiatul.umami@ugm.ac.id \\ (Received 31-03-2021; Revised 18-06-2021; Accepted 28-06-2021)
}

\begin{abstract}
This study aimed to determine the effectiveness of arbuscular mycorrhizal fungi (AMF) in the absorption of nutrients in trapping culture and its effects on the growth and biomass production of corn (Zea mays L.) and sorghum (Sorghum sp.). Soil samples with rhizosphere were collected from three different places: Bambusa sp., Cichorium intybus L., and Pinus merkusii. The density and genus of AMF spores were evaluated. AMF effectiveness was tested using six levels of rhizosphere and two species (corn and sorghum) of plants with a $2 \times 6$ factorial experiment with eight replications of each treatment. Six types of rhizospheres were: (i) bamboo rhizosphere (Bambusa sp.) (T1), (ii) control for T1 (C1), (iii) chicory rhizosphere (C. intybus L.) (T2), (iv) control for T2 (C2), (v) Pine rhizosphere (P. merkusii) (T3), and (vi) control for T3 (C3). The control treatment was derived from sterilized planting media. The results showed that the root rhizosphere of Bambusa sp. had more density and diversity of AMF spores than the root rhizosphere of $C$. intybus $\mathbf{L}$. and $P$. merkusii. At the end of the trapping culture, the host plants sorghum and corn increased the density of spores in the carrier medium or propagules of the three rhizosphere types. The difference in the amount of initial AMF had a significant $(p<0.05)$ effect on plant height, the number of leaves, and the biomass production of trapping plants. It can be concluded that more density and colonization of arbuscular mycorrhizal spores show higher growth and biomass of trapping plants.
\end{abstract}

Keywords: arbuscular mycorrhizal fungi (AMF); forage; sorghum spp.; Zea mays L.

\section{INTRODUCTION}

The livestock sector, including ruminants in Indonesia, is growing, and its population has an upward trend from 15.90 million to 17.05 million for beef cattle and 534 thousand to 550 thousand for dairy cows (Direktorat Jenderal Peternakan dan Kesehatan Hewan, 2018). It causes a major demand for increasing animal feed. Approximately $90 \%$ of ruminant feed comes from forage-grass, browse, legumes, hay, and straw (Minson, 2012). The availability of forage is still considered low at this time. The availability of feed to meet the nutrients requirements is one factor that determines the productivity of ruminants, namely the guaranteed availability of quality forage. Umami et al. (2019) stated that good forage must have high quality, high palatability, and sustainable productivity.

There is low forage availability in the country since most of the land used for growing forage is marginal land, which has various abiotic pressures such as temperature, poor nutrient availability, extreme rainfall, and edaphic factors (Jones et al., 2015). Drought stress, temperature changes, salinity, acidic conditions, light, and nutrient deficiencies cause crops damages (Pandey et al., 2016; Gull et al., 2019; Hussain \& Usman, 2019). Soil quality and its nutrient content affect the quality of forage produced. Soil that is poor in nutrients causes plants to be unable to meet their nutritional needs (Tilman, 2020). The productivity and quality of forages are affected by several factors, including soil fertility, climatic conditions, water availability, and forage defoliation. The negative impacts of climate change on soil fertility and plant mineral nutrition will far outweigh the beneficial effects, which will increase feed insecurity (Clair \& Lynch, 2010). Besides, other factors play an essential role in absorbing plant nutrients, namely the presence of Arbuscular Mycorrhizal Fungi (AMF) in the soil.

Arbuscular mycorrhizal fungi significantly increase the absorption of essential nutrients such as $\mathrm{K}, \mathrm{Mg}$, and $\mathrm{Ca}$, reduce drought stress's damaging effects through antioxidant defense systems, osmolyte synthesis, and maintain phytohormones levels in plants (Al-arjani et al., 2020). Mycorrhizal has several mechanisms of action on plant growth as nutrient absorption, nitrogen fixation, phytohormones, organic acids, enzyme production, and protection against pathogens (Nihorimbere et al., 2011). The abundance of mycorrhizae in the soil varies; this variation has made the researchers explore natural mycorrhizae by isolating them from the rhizosphere of plant roots and multiplying it in trapping cultures. 
Most researchers carry out this propagation, intending to increase the fertility status of marginal lands in food agriculture. In contrast, its application in the livestock sector to increase the quality, quantity, and continuity of forage is still small and limited.

In this research, the researchers tried to isolate mycorrhizae from the root rhizospheres of the Bambusa sp. plant, which has resistance to the dry season, Chicorium intybus L, a type of plant that can grow well in tropical climates, and Pinus merkusii, a type of plant used for land conservation because of its strong roots. In the root rhizospheres of Bambusa sp. and P. merkusii, the explorations of mycorrhizae for propagation to be used in improving the growth and quality of forage plants has never been carried out. There has not been any exploration and propagation of mycorrhizal origin from the root rhizosphere in $C$. intybus $\mathrm{L}$.

Exploration is needed to obtain a high initial diversity of mycorrhizae before propagation by trapping culture. Exploration from various types of soil helps to get an abundance variety of mycorrhizae. Propagation by trapping culture requires a host plant. The association of mycorrhizae with these plants is mutually beneficial for both partners based on a two-way exchange of nutrients (Smith \& Read, 2010; Barea et al., 2013). So far, trapping culture is only used as a multiplication of mycorrhizal spores. However, trapping culture can illustrate the effect of mycorrhiza by evaluating the growth and productivity of host plants to be a reference in the use of AMF in improving forage production. Through this trapping culture, researchers were able to see the diversity of AMF species that could symbiosis and provide positive feedbacks to forage plants. So far, the planting of forage has not paid any attention to the conditions of biotic and abiotic factors that support plant growth.

Plants need balanced biotic and abiotic factors to grow optimally. Environmental abiotic stress harms forage crops which causes a decrease in forage nutrition. One of the efforts to overcome the bad effects of environmental stress is by increasing the biotic components such as AMF. Therefore, by conducting trapping cultures, the diversity of AMF spores can be increased that have a high dependence on host plants to increase the biotic components that can directly play a role in helping the plant growth.

This study aimed to explore indigenous mycorrhiza from the rhizosphere of the roots of Bambusa sp., C. intybus L., P. merkusii, and to evaluate the effects of AMF obtained from the exploration on the Zea mays L. and Sorghum spp. forages host plant.

\section{MATERIALS AND METHODS}

\section{Sampling of Soils with Arbuscular Mycorrhizal Fungi (AMF)}

Soil samples with rhizosphere were collected from three different places with four replications, namely: (i) Sukoharjo region (Bambusa sp); (ii) UGM feed forage farm (C. intybus L), and (iii) Nglinggo pine forests ( $P$. merkusii), Yogyakarta.
Proportional soil or root sampling was carried out based on the specific geometric patterns so that there is a certain distance between one replication point and another replication point. This pattern was generally based on the existing maps and did not really consider the field conditions. Non-proportional sampling was determined based on the actual field conditions. For example, soil sampling was determined based on the distribution of growing vegetation as described by Nusantara et al. (2012).

The density and diversity of AMF spores in soil samples were calculated before and after trapping culture. Spore extraction was performed using the wetsieving technique as described by Pacioni (1992). Firstly, about $100 \mathrm{~g}$ of soil sample were added into 1 liter of water, stirred until homogeneous, and the mixture was kept until large particles were settled. Secondly, the soil suspension was poured on multiple sieves with 125, 63 , and $20 \mu \mathrm{m}$ mesh on the decreasing order and then sprayed with water using a spray flask to facilitate the material to escape. After removal of the first sieve, then the second sieve was re-sprayed with water. Thirdly, the remaining soil was extracted using 125, 63, and $20 \mu \mathrm{m}$ sieves. After that, it was transferred into a centrifuge tube, added $60 \%$ glucose (two times-volume of the extract), and then it was centrifuged at $3000 \mathrm{rpm}$ for 3 minutes. Lastly, the supernatant was poured through filter paper, used a plastic glass to hold the filtrate, and then the filter paper was transferred into a petri dish. Mycorrhizal spores contained in the filter paper were observed using a stereo-microscope, and then the density was calculated, and the genus was identified based on the shape, color, and ornament.

\section{Arbuscular Mycorrhizal Fungi (AMF) Effectiveness Testing}

The AMF effectiveness testing through trapping culture was conducted at the Greenhouse of the Livestock Forage Laboratory, Faculty of Animal Husbandry, Universitas Gadjah Mada (UGM) for a period of 2 months. Six levels of rhizosphere and two species (corn and sorghum) of plants were used for this testing using a $2 \times 6$ factorial experiment with eight replications. Six types of rhizospheres were (i) bamboo rhizosphere (Bambusa sp.) (T1), (ii) control for T1 (C1), (iii) chicory rhizosphere (C. intybus L.) (T2), (iv) control for T2 (C2), (v) pine rhizosphere (P. merkusii) (T3), and (vi) control for T3 (C3). Treatment of control medium came from sterilized rhizosphere and zeolite.

The trapping culture medium included about 100 $\mathrm{g}$ of rhizosphere soil and $100 \mathrm{~g}$ of sterile zeolite, with zeolite-soil-zeolite composition. Corn and sorghum seeds were sown in the nursery. After 5 days of sowing, the seedlings were transplanted onto a polybag (1 seedling/polybag). Plant maintenance, including watering, replanting, fertilizing, and controlling pests, was done for two months. Variables were measured on plant height $(\mathrm{cm})$, the number of leaves (strand), and biomass production $(\mathrm{g})$ at the age of 60 days after planting. 


\section{Statistical Analysis}

The density and genus of AMF in the soil samples and propagules at the end of trapping culture were presented descriptively, while the obtained data for AMF effectiveness testing were analyzed using analysis of variance, and data with significantly different responses were then further tested with Duncan Multiple Range Test at $\mathrm{p}<0.05$.

\section{RESULTS}

\section{Density and Genus of Arbuscular Mycorrhizal Fungi in Soil}

The numbers of spores and diversity of the three rhizosphere soil samples of bamboo roots (Bambusa sp.), Chicory (C. intybus L.), and pine (P. merkusii) are shown in Table 1 . The highest number of spores and diversity was found in bamboo rhizosphere soil samples. The number of spores was 384 spores/100 $\mathrm{g}$ of soil, and its diversity is shown in Figure 1, which contained glomus, gigaspora, and acaulospora. Rhizosphere chicory found 222 spores/100 $\mathrm{g}$ of soil, and its type of diversity is

Table 1. The density and diversity of arbuscular mycorrhizal fungi in soil

\begin{tabular}{llc}
\hline $\begin{array}{c}\text { Type of } \\
\text { rhizosphere }\end{array}$ & \multicolumn{1}{c}{ Type of spores } & $\begin{array}{c}\text { Density of } \\
\text { spores/100 } \\
\text { g soil }\end{array}$ \\
\hline Bambusa sp. & $\begin{array}{l}\text { Glomus sp.1, Glomus sp.2, Glomus } \\
\text { sp.3, Gigaspora sp.1, Gigaspora sp.2, }\end{array}$ & 384 \\
& $\begin{array}{l}\text { Acaulospora sp.1, Acaulospora sp.2 } \\
\text { Cichorium }\end{array}$ & $\begin{array}{l}\text { Glomus sp.4, Acaulospop.3, } \\
\text { intybus L. }\end{array}$ \\
$\begin{array}{l}\text { Acaulospora sp.4 } \\
\text { merkusii }\end{array}$ & $\begin{array}{l}\text { Glomus sp.5, Glomus sp.6, Glomus } \\
\text { sp.7 }\end{array}$ & 222 \\
\hline
\end{tabular}

A 1

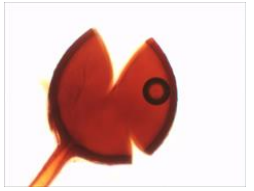

D 1

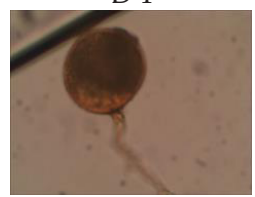

B 1

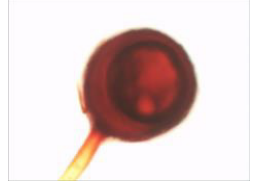

E 1

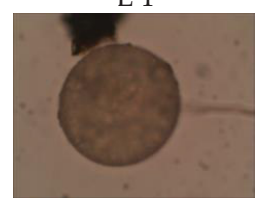

G 1

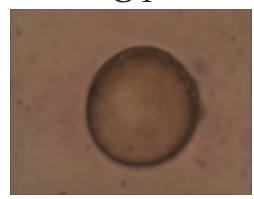

\section{1
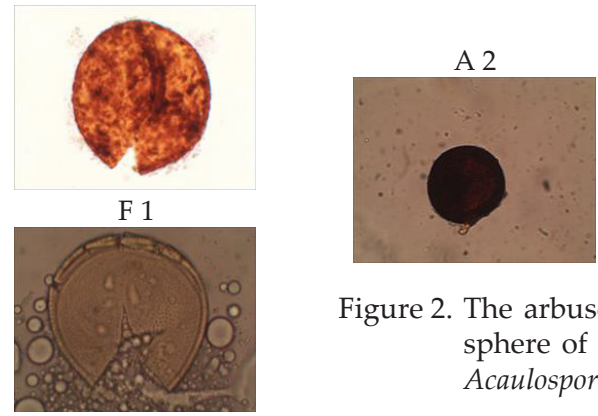

shown in Figure 2, which contained glomus and acaulospora. Rhizosphere pine had 13 spores/100 g of soil, and its diversity type is shown in Figure 3, which contained the lowest glomus among the three samples obtained.

\section{Density of Arbuscular Mycorrhizal Fungi at the End of the Trapping Culture}

The final results of trapping culture obtained propagules in the form of a mixture of rhizosphere and zeolite as a carrier for AMF spores, from the end of plant maintenance for four months, calculated from plant maintenance to plant stressing stage, an increase in the number or density of spores in the propagules was obtained. At the end of the stressing period in the trapping culture of the second forage, the host had an increase in AMF spores every $100 \mathrm{~g}$ of propagules, as shown in Table 2. Hosts of forage sorghum were able to increase the density of AMF spores of the three rhizosphere species at the end of the better stressing of trapping culture. The root rhizosphere of Bambusa sp. from the initial AMF spores of 384 spores/100g rhizosphere soil has increased to 1001 spores/100 g propagules equivalent to 2.60 times the propagation potential of sorghum forage hosts and 552 spores/100 g propagules equivalent to 1.43 times the propagation potential of corn forage hosts.

Sorghum host plants were also able to increase AMF density sourced from the rhizosphere of $C$. intybus L. from 222 spores/100 $\mathrm{g}$ of rhizosphere soil to 761 spores/100 g propagules equivalent to 3.43 times the potential for propagation and in corn plants to 469 spores/100 g propagules equivalent to 2.11 times potential for propagation. The highest density increase was observed in AMF originating from the rhizosphere of $P$. merkusii, which was initially 13 spores $/ 100 \mathrm{~g}$ of rhizosphere soil increased to 394 spores/100 g propagules, which is equal to 30.31 times its propagation potential for sorghum as the host plant, while in corn 243 spores/100 g propagules are equivalent to 18.69 times the potential for reproduction.
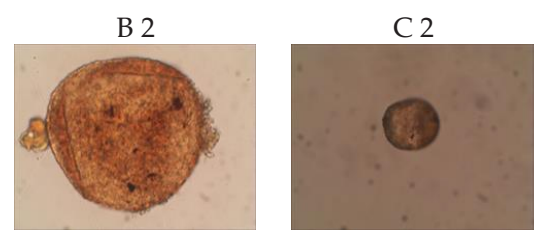

Figure 2. The arbuscular mycorrhizal fungi diversity in rhizosphere of Cichorium intybus L., A2= Glomus sp.4, B2= Acaulospora sp.3. C2= Acaulospora sp.4.
A 3
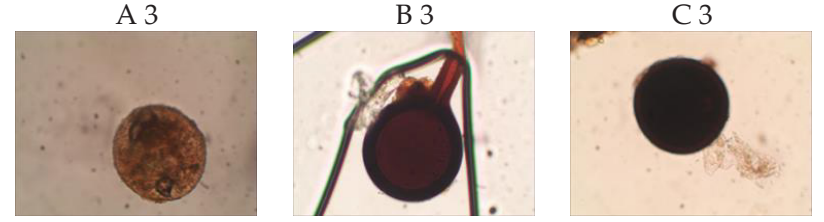

Figure 1. The arbuscular mycorrhizal fungi diversity in rhizosphere rooting of Bambusa sp., A1= Glomus sp.1, B1= Glomus sp.2, C1= Glomus sp.3, D1= Gigaspora sp.1, E1= Gigaspora sp.2, F1= Acaulospora sp.1, G1: Acaulospora sp.2.
Figure 3. The arbuscular mycorrhizal fungi diversity in rhizosphere rooting of Pinus merkusii, A3= Glomus sp.5, B3= Glomus sp.6, C3= Glomus sp.7. 


\section{Arbuscular Mycorrhizal Fungi Effectiveness Testing}

The plant height and number of leaves of the trapping plant are shown in Tables 3 and 4, respectively. Differences in AMF density in different rhizosphere soils had a significant effect $(\mathrm{p}<0.05)$ on plant height. Control plants had an average plant height of 65.3-103.7 $\mathrm{cm}$ in corn and $58.8-83.5 \mathrm{~cm}$ in sorghum. Plants with rhizosphere soil-containing spores showed higher average plant heights in maize $(100.3-116.3 \mathrm{~cm})$ and sorghum $(89.5-122.0 \mathrm{~cm})$ than controls. Bamboo rhizosphere (T1) with a density of 384 AMF spores showed the highest average plant height $(119.2 \mathrm{~cm})$ in both host plants (116.3 for corn and 122.0 for sorghum).

The numbers of leaves in trapping plants are shown in Table 4. Differences in the density of AMF in rhizosphere soils and different types of host plants had a significant effect $(p<0.05)$ on the number of leaves in trapping plants. Plants in rhizosphere soil-containing spores showed a higher number of leaves (13.0-17.0 strands in corn and 9.3-13.0 strands in sorghum) compared to control groups (10.3-13.7 strands in corn and 8.0-10.3 strands in sorghum). Plants with bamboo rhizosphere soil (T1) showed the highest number of leaves (average, 15.0 strands) in both host plants (17.0 in corn and 13.0 in sorghum).

The biomass productions in trapping plants are shown in Table 5. Differences in AMF density in rhizosphere soils and different types of host plants had significant $(p<0.05)$ effects on the biomass of trapping plants. Trapping plants with rhizosphere soils-containing AMF spore showed higher biomass production (73.7-102.7 $\mathrm{g}$ in corn and 32.0-54.3 $\mathrm{g}$ in sorghum) than control groups (44.3-70.7 $\mathrm{g}$ in corn and 23.3-52.7 $\mathrm{g}$ in sorghum). Plants with bamboo rhizosphere soil (T1) with a density of 384 AMF spores showed the highest overall biomass production (average, $78.5 \mathrm{~g}$ ) in both host plants (102.7 $\mathrm{g}$ in corn and $54.3 \mathrm{~g}$ in sorghum).

\section{DISCUSSION}

\section{Density and Genus of Arbuscular Mycorrhizal Fungi in Soils}

Based on Table 1, it can be observed that each soil sample taken from different rhizosphere rooting had different amounts and diversities of AMF. The number of spores in the bamboo rhizosphere was higher than those in the chicory rhizosphere and pine rhizosphere. The numbers of the spores in all samples were relatively low, especially in the pine rhizosphere sample, which was amounted to only 13 spores/100 g soil. The low number of spores may be caused by several factors such as climate, soil temperature, and humidity (Ngwene et al., 2013). It has been documented that the increasing soil temperature can increase the growth of extraradical mycorrhizal hyphae and the length of the roots colonized by the mycorrhizal fungi (Anderson et al., 2013). Factors of plant nutrition, light intensity, and temperature changes due to global warming can also affect the development and diversity of mycorrhizal spores (Sun et al., 2013).

Table 2. The density of arbuscular mycorrhizal fungi at the end of the trapping culture

\begin{tabular}{|c|c|c|c|c|c|}
\hline \multirow[b]{2}{*}{ Type of rhizosphere } & \multirow[b]{2}{*}{$\begin{array}{l}\text { Initial density of } \\
\text { spores/100 g soil }\end{array}$} & \multicolumn{2}{|c|}{ Final density of sorghum propagule } & \multicolumn{2}{|c|}{ Final density of corn propagule } \\
\hline & & $\begin{array}{c}\text { Spores/ } 100 \mathrm{~g} \\
\text { propagule }\end{array}$ & $\begin{array}{c}\text { Propagation } \\
\text { potential }\end{array}$ & $\begin{array}{c}\text { Spores/ } 100 \mathrm{~g} \\
\text { propagule }\end{array}$ & $\begin{array}{c}\text { Propagation } \\
\text { potential }\end{array}$ \\
\hline Bambusa sp. & 384 & 1001 & 2.60 & 552 & 1.43 \\
\hline Cichorium intybus L. & 222 & 761 & 3.43 & 469 & 2.11 \\
\hline Pinus merkusii & 13 & 394 & 30.31 & 243 & 18.69 \\
\hline
\end{tabular}

Table 3. The average height of trapping plants $(\mathrm{cm})$ with different arbuscular mycorrhizal fungi spore densities of rhizosphere soils

\begin{tabular}{lccccccc}
\hline \multirow{2}{*}{ Hosts } & \multicolumn{7}{c}{ Rhizosphere } \\
\cline { 2 - 7 } & C1 & C2 & C3 & T1 & T2 & T3 & Mean \\
\hline Corn & $103.7 \pm 18.6$ & $81.7 \pm 10.6$ & $65.3 \pm 11.5$ & $116.3 \pm 2.9$ & $113.7 \pm 14.3$ & $100.3 \pm 25.9$ & $96.8 \pm 22.7$ \\
Sorghum & $83.5 \pm 4.8$ & $106.6 \pm 21.2$ & $58.8 \pm 6.8$ & $122.0 \pm 22.0$ & $110.3 \pm 7.1$ & $89.5 \pm 5.1$ & $95.1 \pm 24.1$ \\
Mean & $93.6 \pm 16.4^{\mathrm{b}}$ & $94.1 \pm 20.2^{\mathrm{b}}$ & $62.1 \pm 9.1^{\mathrm{a}}$ & $119.2 \pm 14.3^{\mathrm{c}}$ & $112.0 \pm 10.3^{\mathrm{bc}}$ & $94.9 \pm 17.7^{\mathrm{b}}$ & \\
\hline
\end{tabular}

Note: ${ }^{\mathrm{a}, \mathrm{b}, \mathrm{c} M e a n s}$ in the same row with different superscripts differ significantly (p<0.05). C1= control for T1; C2= control for T2; C3= control for T3; T1= bamboo rhizosphere (Bambusa sp.); T2= chicory rhizosphere (Cichorium intybus L.); T3= pine rhizosphere (Pinus merkusii).

Table 4. The average number of leaves in trapping plants (strands) with different arbuscular mycorrhizal fungi spore densities of rhizosphere soils

\begin{tabular}{|c|c|c|c|c|c|c|c|}
\hline \multirow{2}{*}{ Hosts } & \multicolumn{6}{|c|}{ Rhizosphere } & \multirow{2}{*}{ Mean } \\
\hline & $\mathrm{C} 1$ & $\mathrm{C} 2$ & $\mathrm{C} 3$ & T1 & $\mathrm{T} 2$ & T3 & \\
\hline Corn & $13.7 \pm 0.6$ & $13.0 \pm 0.0$ & $10.3 \pm 1.5$ & $17.0 \pm 0.0$ & $14.7 \pm 06$ & $13.0 \pm 1.0$ & $13.6 \pm 2.2^{x}$ \\
\hline Sorghum & $10.3 \pm 0.6$ & $10.0 \pm 0.0$ & $8.0 \pm 0.0$ & $13.0 \pm 0.0$ & $11.3 \pm 0.2$ & $9.3 \pm 1.2$ & $10.3 \pm 1.7^{y}$ \\
\hline Mean & $12.0 \pm 1.9^{\mathrm{b}}$ & $11.5 \pm 1.6^{\mathrm{b}}$ & $9.2 \pm 1.6^{\mathrm{a}}$ & $15.0 \pm 2.2^{\mathrm{d}}$ & $13.0 \pm 2.0^{c}$ & $11.2 \pm 2.2^{\mathrm{b}}$ & \\
\hline
\end{tabular}

Note: a,b,c Means in the same row with different superscripts differ significantly ( $<<0.05) ;, y$ Means in the same column with different superscripts differ significantly $(\mathrm{p}<0.05)$. $\mathrm{C} 1=$ control for $\mathrm{T} 1 ; \mathrm{C} 2=$ control for $\mathrm{T} 2 ; \mathrm{C} 3=$ control for $\mathrm{T} 3$; $\mathrm{T} 1=$ bamboo rhizosphere $($ Bambusa sp.); $\mathrm{T} 2=\mathrm{chicory}$ rhizosphere (Cichorium intybus L.); T3= pine rhizosphere (Pinus merkusii). 
Table 5. The average biomass production of trapping plants $(\mathrm{g})$ with different arbuscular mycorrhizal fungi spore densities of rhizosphere soils

\begin{tabular}{|c|c|c|c|c|c|c|c|}
\hline \multirow{2}{*}{ Hosts } & \multicolumn{6}{|c|}{ Rhizosphere } & \multirow{2}{*}{ Mean } \\
\hline & $\mathrm{C} 1$ & $\mathrm{C} 2$ & $\mathrm{C} 3$ & $\mathrm{~T} 1$ & $\mathrm{~T} 2$ & T3 & \\
\hline Corn & $64.3 \pm 2.5$ & $70.7 \pm 17.6$ & $44.3 \pm 21.8$ & $102.7 \pm 6.8$ & $95.3 \pm 24.8$ & $73.7 \pm 6.5$ & $75.2 \pm 23.9^{x}$ \\
\hline Sorghum & $52.7 \pm 5.7$ & $42.0 \pm 10.6$ & $23.3 \pm 10.6$ & $54.3 \pm 3.1$ & $51.0 \pm 14.8$ & $32.0 \pm 2.0$ & $42.6 \pm 13.8^{y}$ \\
\hline Mean & $58.5 \pm 7.5^{\mathrm{bc}}$ & $56.3 \pm 20.3^{\mathrm{b}}$ & $33.8 \pm 18.6^{\mathrm{a}}$ & $78.5 \pm 26.9^{\mathrm{d}}$ & $73.2 \pm 30.4^{\mathrm{cd}}$ & $52.8 \pm 23.2^{\mathrm{b}}$ & \\
\hline
\end{tabular}

Note: ${ }^{a, b, c}$ Means in the same row with different superscripts differ significantly $(\mathrm{p}<0.05) ;{ }^{x, y}$ Means in the same column with different superscripts differ significantly $(\mathrm{p}<0.05) . \mathrm{C} 1=$ control for $\mathrm{T} 1 ; \mathrm{C} 2=$ control for $\mathrm{T} 2 ; \mathrm{C} 3=$ control for $\mathrm{T} 3$; $\mathrm{T} 1=$ bamboo rhizosphere $($ Bambusa sp.); $\mathrm{T} 2=\mathrm{chicory}$ rhizosphere (Cichorium intybus L.); T3= pine rhizosphere (Pinus merkusii).

The diversity of AMF was evaluated by observing the spores' morphological characteristics such as shape, color, wall, or surface (INVAM, 2017). Bamboo rhizosphere soil (clay and sandy soil structures) had a more diverse AMF, including Glomus, Gigaspora, and Acaulospora compared to the chicory rhizosphere and pine rhizosphere soils (Figure 1). Soil dominated by Gigaspora sand was found in high numbers. Chicory rhizosphere soil showed slightly sandy loam containing Glomus and Acaulospora spores, but cultures have been dominated mostly by Glomus (Figure 2). Clay soil is thought to be a suitable condition for the development of Glomus spores. Belay et al. (2020) stated that clay fractions dominated native forest plots, 37 morphotypes belonging to 12 genera of Glomeromycota were found and dominated by members of Acaulospora and Glomus. In comparison, soil in the rhizosphere of pine roots was found to have the least diversity, dominated by Glomus (Figure 3). The soil in the pine forest has a clay texture and characteristics that are difficult to release water. This factor may be the cause of the low density and diversity of spores in the soil in the rhizosphere of pine roots. Birhane et al. (2018) stated that seasonal changes in soil moisture significantly affected root colonization (RC) and mycorrhizal spore density (SD). In another study, Alguacil et al. (2014) stated that the diversity of AMF was positively correlated with soil parameters related to biological activity.

\section{Density of Arbuscular Mycorrhizal Fungi at the End of the Trapping Culture}

The increase in spore density at the end of the trapping culture indicates a symbiosis between AMF spores and the roots of the host plant. The symbiosis occurs due to pressure from environmental stresses such as low availabilities of water and nutrients so that the AMF sporulation process in the roots is getting wider. AMF fulfills the needs of the host plants by increasing the absorption capacity of nutrients, especially phosphorus (P) and water, while fungi receive carbon compounds from plant photosynthesis (Barea et al., 2013). The final density showed that sorghum and corn had the highest yield from using AMF rhizosphere of Bambusa sp. However, based on the potential for propagation, the rhizosphere of $P$. merkusii has the highest propagation potentials of 30.31 times for sorghum and 18.69 times for corn. The death of spores and the volume of roots formed in the area of the culture pot influenced the number of symbioses that existed, which affects the final number of AMF spores in the planting medium or propagule. Area of culture and the duration of plants in the pots also contribute to the formation of roots meet extents pot.

The dependence of plants on the diversity of the AMF genus also affects the ability of the symbiosis to be established. AMF performs nutrient exchange differently by different host plants due to preferential allocation of photosynthetic and signaling molecules between plants, soil, and microorganisms (Eom et al., 2000; Bever et al., 2009; Nadeem et al., 2014). Zhang et al. (2010) stated that changes in AMF community and density were caused by plant species that produced positive feedback. The diversity of Glomus AMF species has a higher level of symbiosis to host forage plants, and this can also be seen from the propagation potential of AMF originating from the rhizosphere of $P$. merkusii at the end of trapping culture, i.e., 30.31 times in the sorghum host forage plants and 18, 69 times in the corn host forage plant.

\section{Arbuscular Mycorrhizal Fungi Effectiveness Testing}

The differences in plant heights among experimental treatments, as shown in Table 2, can be influenced by the differences in the nutrient uptake due to the symbiosis and colonization of AMF in the rhizosphere of plant roots. It is well known that there is a positive correlation between nutrient availability and growth rate. Mycorrhizal symbiosis in plant roots causes a two-way exchange of nutrients, especially phosphorus $(\mathrm{P})$, for plants that eventually increase productivity (Barea et al., 2013; Smith \& Smith, 2013; Deja-Sikora et al., 2020). AMF can increase phosphorus metabolism through alkaline enzyme activity and acid phosphatase (Al-arjani et al., 2020).

The factors of types of host plants did not show any significant differences in plant height. Different types of plants do not show significant differences in plant height. The morphology of corn plants will undoubtedly be different from those of sorghum plants, both in nutrient absorption and the symbiotic ability of roots to AMF. Differences in host plant metabolism affect the development of spores in the soil, and this condition correlates with the development of the roots in the trapping plant. Besides, this difference may be caused by differences in the genes of each plant. According to Shi et al. (2012), differences in genes in each variety would cause differences in physiological responses even if planted under the same conditions.

The variation in the number of leaves among treatments might be occurred due to the influence of the number of mycorrhizae in the growing media. Pozo et 
al. (2015) stated that mycorrhizae could increase the absorption of nutrients by the host plant and produce growth hormones such as auxin and gibberellins. Auxin functions to stimulate root development that eventually increases nutrients absorptions. Gibberellins stimulate primary growth through the enlargement and cell division that eventually increases plant height and number of leaves. Auxin production has been shown to stimulate root growth that eventually promotes plant growth (Babalola, 2010; Cappellari et al., 2013).

The treatment of pine rhizosphere soil (T3) did not show better performance compared to that of control from sterile bamboo rhizosphere (C1) and the chicory rhizosphere (C2). However, the treatment of pine rhizosphere soil (T3) gave better results compared to control from the sterile rhizosphere of pine (C3). Factors such as water availability, nutrient content, and soil characteristics influence the development of mycorrhizal spores, impacting low biomass. Rhizosphere soil pine had the texture of clay loam where during the rainy season, it contains much water due to its high water-holding capacity. Unusually high water-holding capacity can inhibit the formation of spores. Hawkes et al. (2011) state that changes in rainfall and fluctuations in soil moisture affect the abundance and formation of mycorrhizal spores.

The increased spore density might cause the high plant biomass in rhizosphere soils used as trapping media. Arbuscular mycorrhizal fungi can increase the absorption of plant nutrients and produce growth hormones such as auxin and gibberellins (Pozo et al., 2015). Auxin and gibberellin hormones function to stimulate root development that supports the increased nutrient absorption that stimulates primary growth through cell enlargement and division so that eventually increases both plant height and number of leaves. Plant height, number of leaves, and the diameter of the plant have significant impacts on biomass production. According to Bona et al. (2017), plants with AMF can increase plant diameter compared to plants without AMF. Yang et al. (2016) also state that AMF inoculation increases nutrient absorptions and total plant biomasses in $R$. pseudoacacia, T. pretense, M. sativa, and L. perenne. In addition, inoculations of forage Pennisetum purpureum with AMF increases shoot dry weight production $(34.04 \%)$, crude protein $(10.21 \%)$, phosphorus uptake $(40 \%)$, N content (10.53\%), and N uptake (38.10\%) (Karti et al., 2018).

Soils with high densities of mycorrhizal spores had better biomass than soils without mycorrhizal spores. Avramova et al. (2015) state that drought stress can affect mitosis and cell elongation, decreasing plant growth and yield. Plants with AMF have more benefits and the ability to withstand drought stress (Al-arjani et al., 2020). In addition, different organic-matter contents of the soil can be the cause of differences in biomass. It is consistent with Yang et al. (2016), stating that AMF assists nutrients absorption through the hyphae in the root tissue of host plants, while the production of plant biomass has a close correlation with nitrogen, phosphorus, sulfur, and magnesium. Sterile bamboo rhizosphere control (C1) had similar biomass production with $\mathrm{C} 2$, $\mathrm{T} 2$, and $\mathrm{T} 3$ treatments.

\section{CONCLUSION}

It can be concluded that the growth and biomass of trapping plants increase with the increased density of the rhizosphere AMF. Bamboo rhizosphere with 384 spores gave the best yields on the plant height, leaf number, and biomass production in both trap crops (corn and sorghum). There was an increase in AMF spores on the media or propagules at the end of the trapping culture of the corn and sorghum host forage plants. The highest multiplication potential was obtained in the rhizosphere treatment of Pinus merkusii, which was 30.31 times in the sorghum host plant and 18.69 times in the corn host plant.

\section{CONFLICT OF INTEREST}

We certify that there is no conflict of interest with any financial, personal, or other relationships with other people or organizations related to the material discussed in the manuscript.

\section{ACKNOWLEDGEMENT}

The authors would like to thank the Directorate of Research and Community Service, Ministry of Research, Technology, and Higher Education of the Republic of Indonesia for financial support of the research through Penelitian Dasar Unggulan Perguruan Tinggi or PDUPT 2020.

\section{REFERENCES}

Al-arjani, A. F., A. Hashem, E. Fathi E, \& A. Allah. 2020. Arbuscular mycorrhizal fungi modulates dynamics tolerance expression to mitigate drought stress in Ephedra foliata Boiss. Saudi J. Biol. Sci. 27:380-394. https://doi.org/10.1016/j. sibs.2019.10.008

Alguacil, M. M., E. Torrecillas, F. García-orenes, \& A. Roldán. 2014. Changes in the composition and diversity of AMF communities mediated by management practices in a Mediterranean soil are related with increases in soil biological activity. Soil Biol. Biochem. 76:34-44. https://doi. org/10.1016/j.soilbio.2014.05.002

Anderson, I. C., B. Drigo, K. Keniry, O. Ghannoum, S. M. Chambers, D. T. Tissue, \& J. W. G. Cairney. 2013. Interactive effects of preindustrial, current and future atmospheric $\mathrm{CO} 2$ concentrations and temperature on soil fungi associated with two Eucalyptus species. FEMS Microbiol. Ecol. 83:425-437. https://doi.org/10.1111/1574-6941.12001

Avramova, V., H. Abdelgawad, Z. Zhang, B. Fotschki, R. Casadevall, L. Vergauwen, D. Knapen, E. Taleisnik, Y. Guisez, H. Asard, \& G. T. S. Beemster. 2015. Drought induces distinct growth response, protection, and recovery mechanisms in the maize leaf growth zone. Plant Physiol. 169:1382-1396. https://doi.org/10.1104/pp.15.00276

Babalola, O. O. 2010. Beneficial bacteria of agricultural importance. Biotechnol. Lett. 32:1559-1570. https://doi. org/10.1007/s10529-010-0347-0

Barea, J. M., M. J. Pozo, J. A. López-Ráez, R. Aroca, J. M. RuízLozano, N. Ferrol, R. Azcón, \& C. Azcón-Aguilar. 2013. Arbuscular mycorrhizas and their significance in promoting soil-plant systems sustainability against environmental stresses. In: M. B. Rodelas \& J. Gonzalez-Lopez (Eds). Beneficial plant-microbial interactions: Ecology and applications. CRC Press/Taylor \& Francis, London. pp. 353-387. 
https://doi.org/10.1201/b15251-16

Belay, Z., M. Negash, J. Kaseva, M. Vestberg, \& H. Kahiluoto. 2020. Native forests but not agroforestry systems preserve arbuscular mycorrhizal fungal species richness in southern Ethiopia. Mycorrhiza 30:749-759. https://doi.org/10.1007/ s00572-020-00984-6

Bever, J. D., S. C. Richardson, B. M. Lawrence, J. Holmes, \& M. Watson. 2009. Preferential allocation to beneficial symbiont with spatial structure maintains mycorrhizal mutualism. Ecol. Lett. 12:13-21. https://doi. org/10.1111/j.1461-0248.2008.01254.x

Birhane, E., N. Fatumah, K. Gidey, A. Zenebe, \& S. Mohammed. 2018. Vegetation cover density and disturbance affected arbuscular mycorrhiza fungi spore density and root colonization in a dry Afromontane forest, northern Ethiopia. J. For. Res. 29:675-686. https://doi.org/10.1007/s11676-017-0493-5

Bona, E., S. Cantamessa, N. Massa, P. Manassero, F. Marsano, A. Copetta, G. Lingua, G. D'Agostino, E. Gamalero, \& G. Berta. 2017. Arbuscular mycorrhizal fungi and plant growth-promoting pseudomonads improve yield, quality and nutritional value of tomato: A field study. Mycorrhiza 27:1-11. https://doi.org/10.1007/s00572-016-0727-y

Cappellari, L. del R., M. V. Santoro, F. Nievas, W. Giordano, \& E. Banchio. 2013. Increase of secondary metabolite content in marigold by inoculation with plant growth-promoting rhizobacteria. Appl. Soil Ecol. 70:16-22. https://doi. org/10.1016/j.apsoil.2013.04.001

Clair, S. B. S. \& J. P. Lynch. 2010. The opening of Pandora's Box: Climate change impacts on soil fertility and crop nutrition in developing countries. Plant Soil. 335:101-115. https://doi. org/10.1007/s11104-010-0328-z

Deja-Sikora, E., A. Kowalczyk, A. Trejgell, A. Szmidt-Jaworska, C. Baum, L. Mercy, \& K. Hrynkiewicz. 2020. Arbuscular mycorrhiza changes the impact of potato virus $\mathrm{Y}$ on growth and stress tolerance of Solanum tuberosum L. in vitro. Front. Microbiol. 10:1-12. https://doi.org/10.3389/fmicb.2019.02971

Direktorat Jenderal Peternakan dan Kesehatan Hewan. 2018. Director General of Livestock and Animal Health Services. http://ditjenpkh.pertanian.go.id. [17 December 2019]

Eom, A. H., D. C. Hartnett, \& G. W. T. Wilson. 2000. Host plant species effects on arbuscular mycorrhizal fungal communities in tallgrass prairie. Oecologia 122:435-444. https://doi. org/10.1007/s004420050050

Gull, A., A. A. Lone, \& N. U. I. Wani. 2019. Biotic and Abiotic Stresses in Plants. In: Alexandre Bosco de Oliveira (Eds). Abiotic and biotic stress in plants. IntechOpen, London. p. 1-19. Chapter 66714. https://doi.org/10.5772/ intechopen.85832

Hawkes, C. V., S. N. Kivlin, J. D. Rocca, V. Huguet, M. A. Thomsen, \& K. B. Suttle. 2011. Fungal community responses to precipitation. Glob. Chang. Biol. 17:1637-1645. https:// doi.org/10.1111/j.1365-2486.2010.02327.x

Hussain, F. \& F. Usman. 2019. Fungal Botic Stresses in Plants and its Control Strategy. In: Alexandre Bosco de Oliveira (Eds). Abiotic and Biotic Stress in Plants. IntechOpen, London. Chapter 65038. https://doi.org/10.5772/intechopen.83406

INVAM. 2017. International culture collection of (vesicular) arbuscular mycorrhizal fungi. West Virginia University. http://fungi.invam.wvu.edu/.[10 Oktober 2020]

Jones, M. B., J. Finnan, \& T. R. Hodkinson. 2015. Morphological and physiological traits for higher biomass production in perennial rhizomatous grasses grown on marginal land. Gcb Bioenergy 7:375-385. https://doi.org/10.1111/ gcbb.12203

Karti, P. D. M. H., I. Prihantoro, \& M. A. Setiana. 2018. Evaluation of arbuscular mycorrhizal fungi inoculum on production and nutrient content of Pennisetum purpureum. Trop. Anim. Sci. J. 41:114-120. https://doi.org/10.5398/tasj.2018.41.2.114

Minson, D. 2012. Forage in Ruminant Nutrition. $1^{\text {st }}$ Ed. Academic
Press (Elsevier), Cambridge.

Nadeem, S. M., M. Ahmad, Z. A. Zahir, A. Javaid, \& M. Ashraf. 2014. The role of mycorrhizae and plant growth promoting rhizobacteria (PGPR) in improving crop productivity under stressful environments. Biotechnol. Adv. 32:429-448. https:// doi.org/10.1016/j.biotechadv.2013.12.005

Ngwene, B., E. Gabriel, \& E. George. 2013. Influence of different mineral nitrogen sources ( $\mathrm{NO} 3--\mathrm{N}$ vs. NH 4+-N) on arbuscular mycorrhiza development and $\mathrm{N}$ transfer in a Glomus intraradices-cowpea symbiosis. Mycorrhiza 23:107-117. https://doi.org/10.1007/s00572-012-0453-z

Nihorimbere, V., M. Ongena, M. Smargiassi, \& P. Thonart. 2011. Beneficial effect of the rhizosphere microbial community for plant growth and health. Biotechnol. Agron. Soc. Envir. 15:327-337.

Nusantara, A. D., R.Y.H. Bertham, \& I. Mansur. 2012. Bekerja dengan Fungi Mikoriza Arbuskula. SEAMEO BIOTROP, Bogor. http://repository.unib.ac.id/7590/2/B09a\%20 Bekerja\%20Dengan\%20Fungi\%20Mikoriza\%20Arbuskula. pdf [22 October 2020].

Pacioni, G. 1992. 16 Wet-sieving and decanting techniques for the extraction of spores of vesicular-arbuscular fungi. Methods Microbiol. 24:317-322. https://doi.org/10.1016/ S0580-9517(08)70099-0

Pandey, V., M. W. Ansari, S. Tula, S. Yadav, R. K. Sahoo, N. Shukla, G. Bains, S. Badal, S. Chandra, A. K. Gaur, A. Kumar, A. Shukla, J. Kumar, \& N. Tuteja. 2016. Dosedependent response of Trichoderma harzianum in improving drought tolerance in rice genotypes. Planta 243:1251-1264. https://doi.org/10.1007/s00425-016-2482-x

Pozo, M. J., J. A. López-Ráez, C. Azcón-Aguilar, \& J. M. GarcíaGarrido. 2015. Phytohormones as integrators of environmental signals in the regulation of mycorrhizal symbiose. New Phytol. 205:1431-1436. https://doi.org/10.1111/nph.13252

Shi, H., Y. Wang, Z. Cheng, T. Ye, \& Z. Chan . 2012. Analysis of natural variation in bermudagrass (Cynodon dactylon) reveals physiological responses underlying drought tolerance. PLoS ONE 7:e53422. https://doi.org/10.1371/journal.pone. 0053422

Smith, F. A. \& S. E. Smith. 2013. How useful is the mutualismparasitism continuum of arbuscular mycorrhizal functioning?. Plant Soil. 363:7-18. https://doi.org/10.1007/ s11104-012-1583-y

Smith, S. E. \& D. J. Read. 2010. Mycorrhizal Symbiosis. Academic Press, Cambridge.

Sun, X. F., Y. Y. Su, Y. Zhang, M. Y. Wu, Z. Zhang, K. Q. Pei, L. F. Sun, S. Q. Wan, \& Y. Liang. 2013. Diversity of arbuscular mycorrhizal fungal spore communities and its relations to plants under increased temperature and precipitation in a natural grassland. Chin. Sci. Bull. 58:4109-4119. https://doi. org/10.1007/s11434-013-5961-5

Tilman, D. 2020. Plant Strategies and the Dynamics and Structure of Plant Communities. (MPB-26). Vol. 26. Princeton University Press, New Jersey. https://doi.org/10.2307/j. ctvx5w9ws

Umami, N., A. Abdiyansah, \& A. Agus. 2019. Effects of different doses of NPK fertilization on growth and productivity of Cichorium intybus. In: IOP Conference Series: Earth and Environmental Science. IOP Publishing, Yogyakarta. p. 12097. https://doi.org/10.1088/1755-1315/387/1/012097

Yang, Y., Y. Liang, X. Han, T. Y. Chiu, A. Ghosh, H. Chen, \& M. Tang. 2016. The roles of arbuscular mycorrhizal fungi $(\mathrm{AMF})$ in phytoremediation and tree - herb interactions in $\mathrm{Pb}$ contaminated soil. Sci. Rep. 6:20469. https://doi.org/10.1038/ srep20469

Zhang, Q., R. Yang, J. Tang, H. Yang, S. Hu, \& X. Chen. 2010. Positive feedback between mycorrhizal fungi and plants influences plant invasion success and resistance to invasion. PLoS ONE 5:e.12380. https://doi.org/10.1371/journal. pone. 0012380 